\title{
Functional mitral regurgitation and papillary muscle dyssynchrony in patients with left ventricular systolic dysfunction
}

\author{
Sol ventrikül sistolik disfonksiyonu olan hastalarda işlevsel mitral yetersizliğgi ve \\ papiller kas dissenkronisi
}

Ahmet Güler, Cihan Dündar, Kürşat Tigen

Cardiology Clinic, Kartal Koşuyolu Training and Research Hospital, İstanbul-Turkey

In a dilated heart with impaired systolic functions, functional mitral regurgitation could be seen even in the presence of structurally normal mitral apparatus. A number of mechanisms play role in the development of functional mitral regurgitation. These are increased mitral tethering forces, reduction in closing forces and mechanical and electrical dyssynchrony. Papillary muscle dyssynchrony has also been shown to be related with functional mitral regurgitation. Cardiac resynchronization therapy is known to reduce the amount of functional mitral regurgitation in patients with left ventricular systolic failure although some may not respond to treatment with cardiac resynchronization therapy. Papillary muscle dyssynchrony may predict the response of cardiac resynchronization therapy on the regression of functional mitral regurgitation and may suggest the suitable therapeutic options, such as cardiac resynchronization therapy, mitral valve repair, coronary revascularization separately or in combination. In this review, the mechanisms of functional mitral regurgitation, papillary muscle dyssynchrony and its relationship with functional mitral regurgitation and the relationship of papillary muscle dyssynchrony with the improvement of functional mitral regurgitation after cardiac resynchronization therapy are focused. (Anadolu Kardiyol Derg 2011; 11: 450-5)

Key words: Papillary muscle dyssynchrony, functional mitral regurgitation, cardiac resynchronization therapy

ÖZET

Sistolik fonksiyonları bozuk olan genişlemiş bir kalpte, mitral kapakta yapısal bir bozukluk olmasa bile fonksiyonel olarak yetersizlik meydana gelebilir. Fonksiyonel mitral yetersizliğinin gelişmesinde birçok mekanizma beraber rol alır. Bunlar, mitral kapağı kalbin apeksine doğru çeken kuvvetlerdeki artış, sistol sırasında kapağı kapayıcı kuvvetlerdeki azalma ve mekanik ve elektriksel dissenkronidir. Papiller adele dissenkronisi de fonksiyonel mitral yetersizliğine katkıda bulunan nedenlerden biridir. Sistolik kalp yetersizliği olan hastalarda -bazı durumlarda yanıt alınamayabilirse de- kardiyak resenkronizasyon tedavisi ile fonksiyonel mitral yetersizliğinin gerilediği bilinir. Papiller adele dissenkronisi fonksiyonel mitral yetersizliğinin gerilemesi bakımından kardiyak resenkronizasyon tedavisine yanıtı tahmin edebilir ve koroner revaskülarizasyon, mitral onarım veya kardiyak resenkronizasyon tedavisi gibi farklı tedavilerden hangisinin seçileceği ya da beraber uygulanacağı konusunda yol gösterici olabilir. Bu derlemede fonksiyonel mitral yetersizliğinin mekanizmaları, papiller adele dissenkronisi ve fonksiyonel mitral yetersizliği arasındaki ilişki, papiller adele dissenkronisi ile kardiyak resenkronizasyon tedavisi sonrası fonksiyonel mitral yetersizliğindeki gerileme arasındaki ilişki incelenmiştir. (Anadolu Kardiyol Derg 2011; 11: 450-5)

Anahtar kelimeler: Papiller adele dissenkronisi, fonksiyonel mitral yetersizliği, kardiyak resenkronizasyon tedavisi

Address for Correspondence/Yazışma Adresi: Dr. Ahmet Güler, Cardiology Clinic, Kartal Koşuyolu Training and Research Hospital, İstanbul-Turkey Phone: +90 2164594041 Fax: +90 2164596321 E-mail: ahmetguler01@yahoo.com.tr

Accepted Date/Kabul Tarihi: 14.02.2011 Available Online Date/Çevrimiçi Yayın Tarihi: 05.07.2011

(C) Telif Hakkı 2011 AVES Yayıncılık Ltd. Şti. - Makale metnine www.anakarder.com web sayfasından ulaşılabilir.

(C) Copyright 2011 by AVES Yayıncllk Ltd. - Available on-line at www.anakarder.com doi:10.5152/akd.2011.113 


\section{Introduction}

In a dilated heart with impaired systolic functions, functional mitral regurgitation (FMR) could be seen even though the mitral apparatus is structurally normal. FMR is associated with decreased survival in patients with left ventricular systolic dysfunction and the mortality increases in parallel with the severity of FMR (1-4). A number of mechanisms play role in the development of FMR. The suggested mechanisms for FMR in patients with left ventricular systolic dysfunction are the decrease in the transmitral pressure force which impairs effective mitral valve closure, the geometrical changes in the mitral annulus, papillary muscle, and mitral valve, and the dyssynchronic left ventricular and papillary muscle contractions (5-8).

Medical treatment alone is often insufficient in the management of clinically significant FMR, and additional therapy such as cardiac resynchronization therapy (CRT), surgical mitral valve repair or coronary revascularization of ischemic myocardium may be required. CRT reduces the amount of FMR in patients with left ventricular (LV) systolic failure (9-14). Studies have shown that the severity of FMR was correlated with the papillary muscle dyssynchrony (PMD) (15-18). Moreover, PMD was found to predict the improvement of FMR after CRT and help make the choice of treatment options such as CRT with or without mitral valve repair. PMD can also be a guiding parameter in performing mitral valve repair in those patients with low ejection fraction (EF) who are candidates for surgical coronary revascularization.

In this review, the mechanisms of FMR, PMD and its relationship with FMR and the relationship of PMD with the improvement of FMR after CRT are focused.

\section{Mechanism of functional mitral regurgitation}

FMR is seen secondary to structural and functional changes in a dilated heart (Fig. 1). The mechanisms responsible are increased mitral tethering forces, reduction in closing forces and mechanical and electrical dyssynchrony $(5-8,19-21)$. As the dilating heart becomes more spherical, the papillary muscles

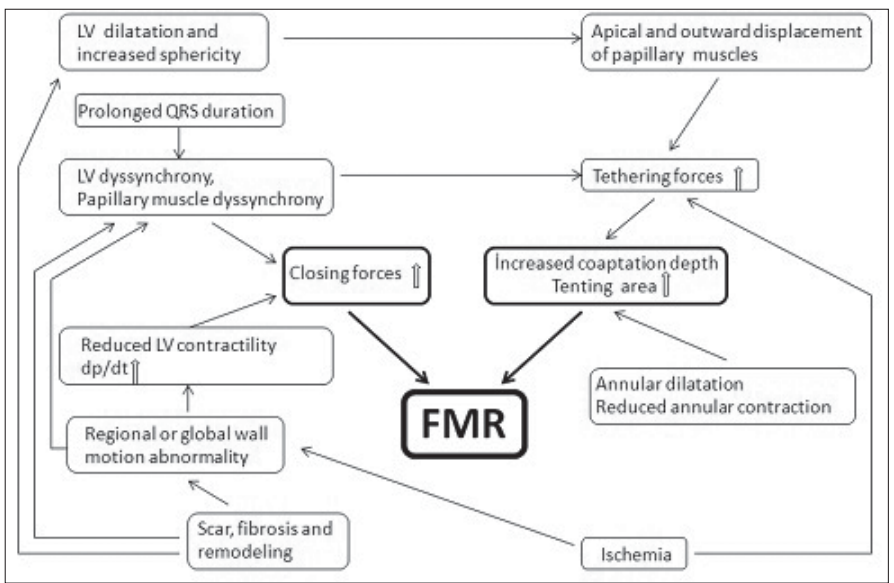

Figure 1. Mechanisms of functional mitral regurgitation

FMR-functional mitral regurgitation, LV-left ventricle displaces outwards and towards the apex. Consequently, increased tethering forces enhances the traction of the mitral apparatus causing incomplete coaptation which occurs at a level closer to the apex (Fig. 2) (5). In addition, annular dilation further worsens the process. Impaired and dyssynchronic contraction of the LV, decreased dp/dt attenuates the closing force, thereby increases the FMR (19). Moreover, decreased longitudinal myocardial contraction especially the wall underlying papillary muscles also takes part in increasing tethering forces. Increased intraventricular electrical delay, indicated by prolongation of QRS duration, also play a role in the development of FMR. In a previous study, moderate to severe FMR was found to be more common in patients with a QRS duration $\geq 130 \mathrm{~ms}$ (21).

\section{The relationship between functional mitral regurgitation and papillary muscle dyssynchrony}

One of the vital mechanisms causing FMR is PMD. Bundle branch blocks and abnormal intraventricular conduction can occur secondary to ventricular dilatation, scar, fibrosis and ischemia. In addition, impaired contraction of the papillary muscles itself and the adjacent myocardial segments occurs due to ischemia, scar or remodeling. The resulting dyssynchronic contractions of LV segments and papillary muscles play a role in the development of functional MR $(9,15-18,22)$.

Soyama et al. (15) showed that the dyssynchrony between myocardial segments adjacent to papillary muscle is one of the responsible mechanisms for FMR. In this study with dilated cardiomyopathy patients, the difference between time to peak systolic myocardial strain of myocardial segments adjacent to medial and lateral papillary muscles was found to be related with FMR. Similarly, in another recent study, regional myocardial dyssynchrony was found to be related with FMR (16).

Two-dimensional speckle-tracking imaging enables the angleindependent assessment of multidirectional LV strain and differentiates myocardial segments with active contraction from segments that are passively tethered $(23,24)$. Generally, most of the CRT studies regarding papillary muscle dyssynchrony and FMR

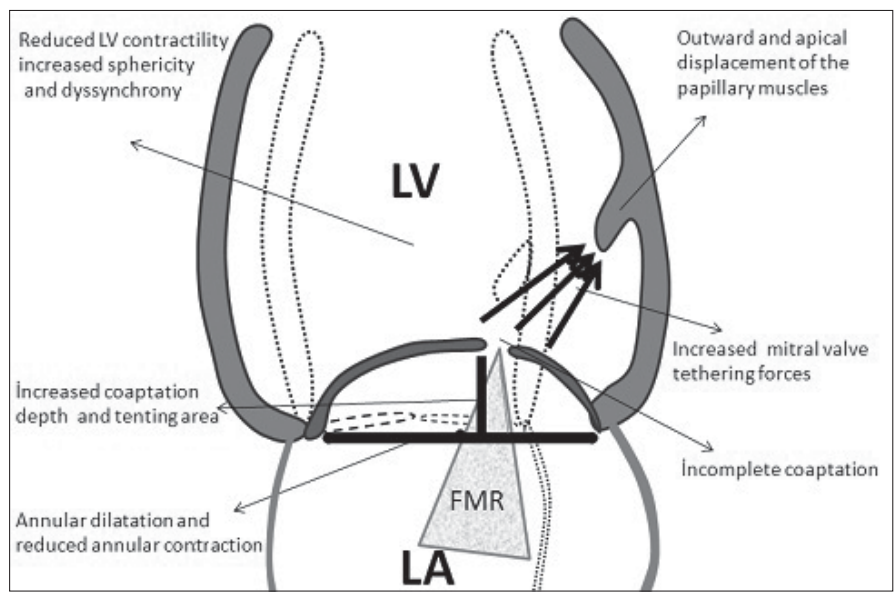

Figure 2. Schematic representation of the underlying mechanisms of functional mitral regurgitation

FMR- functional mitral regurgitation, LA- left atria, LV- left ventricle 
have investigated the possible papillary muscle insertion regions on the LV in their radial and longitudinal analysis (Fig. 3A).

In our recent publication, we used direct strain analysis of the papillary muscles themselves in apical 3 and 4 chamber views (18). Using direct strain analysis of papillary muscles, the average value of peak systolic longitudinal strain for each papillary muscle was determined. The beginning of the ORS complex was used as the reference point and the time to peak systolic longitudinal strain was quantified for each papillary muscle (Fig. 3B). For the assessment of papillary muscle systolic dyssynchrony, the difference in the time to peak systolic longitudinal strain between anterolateral and posteromedial papillary muscles was calculated. Papillary muscle dyssynchrony measurements were significantly different in the various FMR levels (mild/moderate/moderate-to-severe FMR, 22/45/58 ms, respectively $\mathrm{p}<0.0001)$. We found that significant PMD ( $>30 \mathrm{~ms}$ ) was the only independent predictor of moderate or moderate to-severe FMR.

\section{Cardiac resynchronization therapy and functional mitral regurgitation}

The clinical effects of long-term CRT have been evaluated in a large number of randomized multi centre trials with crossover or parallel treatment assignment $(9,11,25-29)$. CRT has been demonstrated to improve heart failure symptoms, exercise capacity, morbidity and mortality in patients with heart failure (NYHA function class III/IV LVEF $<35 \%$, QRS $>120 / 130$ ms, sinus rhythm) $(9,11,29,30)$. A consistent finding in the randomized trials designed with up to 6 months of follow-up has been an up to $15 \%$ absolute reduction in LV end-diastolic diameter and an up to $6 \%$ increase in EF following CRT $(31,32)$.

CRT reduces the amount of FMR in patients with LV systolic failure $(9-14,33-38)$. Effects of CRT on FMR are acute and longterm, due to the reverse remodeling of the LV. In the early period after CRT, the dyssynchrony of papillary muscles and neighboring myocardium decreases, the global systolic functions and consequently closing forces improve, and tethering of mitral
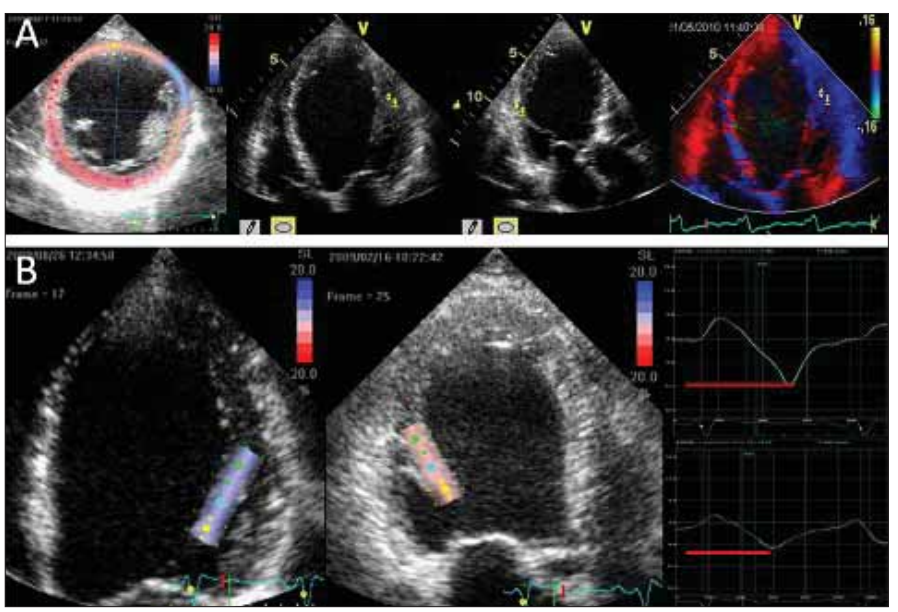

Figure 3. A-Assessment of the papillary muscle dyssynchrony by evaluating the dyssynchrony of adjacent myocardial segments, BAssessment of papillary muscle dyssynchrony by direct calculation of the time to peak systolic longitudinal strain of each papillary muscle at apical 4- and 3-chamber views apparatus lessens. Thus, improvement of FMR is seen. Longterm improvement in FMR after CRT was brought about by LV reverse remodeling, global LV remodeling and improved mitral deformation indices $(33,34,37,39)$.

Breithardt et al. (39) studied 24 heart failure patients who were candidates for CRT, and the severity of FMR was found to improve immediately after CRT, with a reduction in effective regurgitant orifice area from $25 \pm 19 \mathrm{~mm}^{2}$ to $13 \pm 8 \mathrm{~mm}^{2}(\mathrm{p}<0.01)$. Similarly, Kanzaki et al. (36) also demonstrated the reduction in FMR severity in the early period after CRT (regurgitant volume decreased from $40 \pm 20 \mathrm{ml}$ to $24 \pm 17 \mathrm{ml} \mathrm{p}<0.01$ ). They studied the deformation sequence of the papillary muscles by strain rate imaging and reported a direct relation between the interpapillary muscle activation time delay and the improvement in MR degree by CRT. In a study done by Goland et al. (40) with 32 CRT candidates, inferoanterior time delay by $2 \mathrm{D}$ radial strain $>110 \mathrm{~ms}$ and the presence of non-severe MR were found to be significant predictors of decrease in MR after CRT. In light of these studies, acute reduction in FMR could be ascribed to the improvement of mechanical coordination in the myocardium underlying papillary muscles with the resultant resynchronization of papillary muscles.

Decrease in PMD after CRT exerts its positive effects on FMR early in acute phase and continues in the long run. Ypenburg et al. (13) reevaluated 25 patients with regressed FMR in the acute period after CRT after 6 months. After temporary interruption of CRT, acute loss of papillary muscles resynchronization and acute recurrence of FMY was seen (from $26 \pm 28 \mathrm{~ms}$ to $134 \pm 51 \mathrm{~ms} ; \mathrm{p}<0.001)$. The improvement of MR was more prominent in the acute phase after CRT but it continues in the long term with reverse remodeling of the ventricle. In a recent study, 68 DCM patients with FMR (LV ejection fraction $23 \pm 8 \%$, MR > grade $1+$ ) was evaluated and followed after CRT, and the regression of FMR was seen in $43 \%$ soon after CRT but the improvement was seen in $20 \%$ only after 6 months. Both groups had similar extent of LV dyssynchrony however, the site of latest activation in early responders was mostly inferior or posterior (adjacent to the posterior papillary muscle), whereas the lateral wall was the latest activated segment in late responders (41).

Patients with LV systolic dysfunction and narrow QRS complexes are not indicated for CRT (42). Rethin0 trial (43) showed that no clinical benefit in patients with QRS duration less than 130 ms even if concomitant mechanical dyssynchrony was present according to standard echocardiographic parameters. However, Achilli et al. (44) demonstrated the improvement in FMR in 14 narrow QRS patients after CRT. In a recently published study from our institution, we used the TDI-based longitudinal strain of papillary muscles, and we reported that $60 \mathrm{~ms}$ cut-off value of the papillary muscle dyssynchrony predicted the FMR volume $>20 \mathrm{~mL}$ in DCM patients with narrow QRS complex (17). Evaluating of papillary muscle dyssynchrony may be useful in determining the response of CRT improvement of FMR in patients with reduced left ventricular function and narrow QRS intervals. 
The usefulness of assessing papillary muscle dyssynchrony in the decision making of concomitant mitral valve repair in patients undergoing coronary bypass surgery (CABG)

Mitral valve repair for patients undergoing CABG is recommended in patients with severe preoperative mitral regurgitation $(45,46)$. On the other hand, the indication for concomitant mitral valve repair in the patient who undergoes CABG with mild to moderate mitral regurgitation is still unclear. The persistence of moderate FMR after isolated CABG is an important independent predictor of long-term mortality (47). With surgical revascularization, myocardial ischemia decreases and reverse ventricular remodeling is expected in the long run. It is hard to predict if the moderate mitral regurgitation will regress with coronary revascularization. At the same time, operative mortality is raised by mitral valve annuloplasty (48). In a study done by Penica et al. (49) 135 patients with low EF and moderate mitral regurgitation who underwent $C A B G$ without mitral valve repair were followed. In a 12-month follow-up, mitral regurgitation regressed in approximately half of the patients. Before coronary artery bypass graft surgery, the patients with improved mitral regurgitation had significantly more viable myocardium and less dyssynchrony between papillary muscles $(<60 \mathrm{~ms})$ than the failure group $(p<0.001)$.

Papillary muscle dyssynchrony may provide a basis for clinical decision making as to whether mitral valve repair should be performed at the time of surgical revascularization in patients with moderate mitral regurgitation referred for elective CABG. However, more extensive studies are still needed.

\section{Could papillary muscle dyssynchrony predict the response to cardiac resynchronization therapy?}

A fraction of patient (approximately 30\%) do not respond to treatment with CRT (50). The exact underlying reasons are not clear but some clinical and echocardiographic parameters could predict the lack of improvement after CRT. Ischemic etiology of cardiomyopathy, irreversible restrictive transmitral diastolic pattern, short QRS duration ( $<120 \mathrm{~ms})$, prolonged PR interval and RBBB have been shown to be the most powerful predictors $(32,51,52)$. Another known predictor is the presence of severe mitral regurgitation. Cabrera-Bueno et al. (53) demonstrated that the presence of severe mitral regurgitation at baseline was associated with a lack of response in reverse remodeling in patients with nonischemic dilated cardiomyopathy, although there was significant improvement in FMR and intraventricular dyssynchrony. The presence of a significant volume overload due to severe FMR appears as a factor promoting further LV dilatation and blocking the LV reverse remodeling process. Surgical correction of mitral valve increases survival, but is associated with a relatively higher risk for perioperative complications and mortality. Moreover, a recent retrospective analysis failed to show survival benefit of mitral valve repair in patients with end-stage heart failure (54). PMD could be clinically important to determine the patients with heart failure, whose FMR would improve after CRT.

\section{Conclusion}

PMD plays an important role in the pathophysiology of FMR in the patients with left ventricular systolic dysfunction resulting in serious morbidity and mortality, and is related with the severity of the mitral regurgitation. PMD may predict the response of CRT on the regression of FMR. However, a number of different methods have been applied for the evaluation of PMD and different cut-off values have been found to be indicative of dyssynchrony. Large-scale studies are needed to determine an acceptable method and cut-off value for PMD. Moreover, PMD in the presence FMR could be a guiding tool in the evaluation of the effect of surgical or percutaneous revascularization on FMR, the decision for mitral repair or even the decision on the combined management with CRT, revascularization and mitral repair. The optimal management could be determined by large-scale studies of different treatment options in patients with FMR.

Conflict of interest: None declared.

\section{References}

1. Blondheim DS, Jacobs LE, Kotler MN, Costacurta GA, Parry WR. Dilated cardiomyopathy with mitral regurgitation: decreased survival despite a low frequency of left ventricular thrombus. Am Heart $\mathrm{J}$ 1991; 122: 763-71.

2. Junker A, Thayssen $P$, Nielsen $B$, Andersen PE. The hemodynamic and prognostic significance of echo-Doppler-proven mitral regurgitation in patients with dilated cardiomyopathy. Cardiology 1993; 83: 14-20.

3. Peteiro J, Bendayan I, Marinas J, Campos R, Bouzas B, CastroBeiras A. Prognostic value of mitral regurgitation assessment during exercise echocardiography in patients with left ventricular dysfunction: a follow-up study of 1.7+1.5 years. Eur $\mathrm{J}$ Echocardiogr 2008; 9: 18-25.

4. Trichon BH, Felker GM, Shaw LK, Cabell CH, O'Connor CM. Relation of frequency and severity of mitral regurgitation to survival among patients with left ventricular systolic dysfunction and heart failure. Am J Cardiol 2003; 91: 538-43.

5. Watanabe N, Ogasawara Y, Yamaura Y, Kawamoto T, Toyota E, Akasaka $T$, et al. Quantitation of mitral valve tenting in ischemic mitral regurgitation by transthoracic real-time three-dimensional echocardiography. J Am Coll Cardiol 2005; 45: 763-9.

6. Kaul S, Spotnitz WD, Glasheen WP, Touchstone DA. Mechanism of ischemic mitral regurgitation. An experimental evaluation. Circulation 1991; 84: 2167-80.

7. Tibayan FA, Rodriguez F, Zasio MK, Bailey L, Liang D, Daughters GT, et al. Geometric distortions of the mitral valvular-ventricular complex in chronic ischemic mitral regurgitation. Circulation 2003; 108: 116-21.

8. Lai DT, Tibayan FA, Myrmel T, Timek TA, Dagum P, Daughters GT, et al. Mechanistic insights into posterior mitral leaflet inter-scallop malcoaptation during acute ischemic mitral regurgitation. Circulation 2002; 106: 140-5.

9. Cleland JG, Daubert JC, Erdmann E, Freemantle N, Gras D, Kappenberger $L$, et al. Cardiac Resynchronization-Heart Failure (CARE-HF) Study Investigators: the effect of cardiac resynchronization 
on morbidity and mortality in heart failure. N Engl J Med 2005; 352: 1539-49.

10. Breithardt OA, Sinha AM, Schwammenthal E, Bidaoui N, Markus KU, Franke $A$, et al. Acute effects of cardiac resynchronization therapy on functional mitral regurgitation in advanced systolic heart failure. J Am Coll Cardiol 2003; 41: 765-70.

11. Bristow MR, Saxon LA, Boehmer J, Krueger S, Kass DA, De Marco T, et al. Comparison of Medical Therapy, Pacing, and Defibrillation in Heart Failure (COMPANION) Investigators: cardiac resynchronization therapy with or without an implantable defibrillator in advanced chronic heart failure. N Engl J Med 2004; 350: 2140-50.

12. Karvounis HI, Dalamaga EG, Papadopoulos CE, Karamitsos TD, Vassilikos V, Paraskevaidis $S$, et al. Improved papillary muscle function attenuates functional mitral regurgitation in patients with dilated cardiomyopathy after cardiac resynchronization therapy. J Am Soc Echocardiogr 2006; 19: 1150-7.

13. Ypenburg C, Lancellotti P, Tops LF, Bleeker GB, Holman ER, Pierard $L A$, et al. Acute effects of initiation and withdrawal of cardiac resynchronization therapy on papillary muscle dyssynchrony and mitral regurgitation. J Am Coll Cardiol 2007; 50: 2071-7.

14. Porciani MC, Macioce R, Demarchi G, Chiostri M, Musilli N, Cappelli $F$, et al. Effects of cardiac resynchronization therapy on the mechanisms underlying functional mitral regurgitation in congestive heart failure. Eur J Echocardiogr 2006; 7: 31-9.

15. Soyama A, Kono T, Mishima T, Morita H, Ito T, Suwa M, et al. Intraventricular dyssynchrony may play a role in the development of mitral regurgitation in dilated cardiomyopathy. J Card Fail 2005; 11: 631-7.

16. Agricola E, Oppizzi M, Galderisi M, Pisani M, Meris A, Pappone C, et al. Role of regional mechanical dyssynchrony as a determinant of functional mitral regurgitation in patients with left ventricular systolic dysfunction. Heart 2006; 92: 1390-5.

17. Tigen K, Karaahmet T, Gürel E, Çevik C, Otahbachi M, Pala S, et al. Papillary muscle dyssynchrony as a cause of functional mitral regurgitation in non-ischemic dilated cardiomyopathy patients with narrow QRS complexes. Anadolu Kardiyol Derg 2009; 9: 196-203.

18. Tigen K, Karaahmet T, Dündar C, Güler A, Çevik C, Başaran O, et al. The importance of papillary muscle dyssynchrony in predicting the severity of functional mitral regurgitation in patients with nonischaemic dilated cardiomiopathy: a two-dimensional speckletracking echocardiography study. Eur J Echocardiogr 2010; 11: 671-6.

19. He S, Fontaine AA, Schwammenthal E, Yoganathan AP, Levine RA. Integrated mechanism for functional mitral regurgitation: leaflet restriction versus coapting force: in vitro studies. Circulation 1997; 96: 1826-34.

20. Porciani MC, Dondina C, Macioce R, Demarchi G, Pieragnoli P, Musilli $\mathrm{N}$, et al. Echocardiographic examination of atrioventricular and interventricular delay optimization in cardiac resynchronization therapy. Am J Cardiol 2005; 95: 1108-10.

21. Erlebacher JA, Barbarash S. Intraventricular conduction delay and functional mitral regurgitation. Am J Cardiol 2001; 88: 83-6.

22. Donal E, De Place C, Kervio G, Bauer F, Gervais R, Leclercq C, et al. Mitral regurgitation in dilated cardiomyopathy: value of both regional left ventricular contractility and dyssynchrony. Eur J Echocardiogr 2009; 10: 133-8.

23. Leitman M, Lysyansky P, Sidenko S, Shir V, Peleg E, Binenbaum M, et al. Two-dimensional strain-a novel software for real-time quantitative echocardiographic assessment of myocardial function. J Am Soc Echocardiogr 2004; 17: 1021-9.
24. Perk G, Tunick PA, Kronzon I. Non-Doppler two-dimensional strain imaging by echocardiography-from technical considerations to clinical applications. J Am Soc Echocardiogr 2007; 20: 234-43.

25. Abraham WT, Fisher WG, Smith AL, Delurgio DB, Leon AR, Loh E, et al. Cardiac resynchronization in chronic heart failure. $\mathrm{N}$ Engl $\mathrm{J}$ Med 2002; 346: 1845-53.

26. Auricchio A, Stellbrink C, Sack S, Block M, Vogt J, Bakker P, et al. Long-term clinical effect of hemodynamically optimized cardiac resynchronization therapy in patients with heart failure and ventricular conduction delay. J Am Coll Cardiol 2002; 39: 2026-33.

27. Higgins SL, Hummel JD, Niazi IK, Giudici MC, Worley SJ, Saxon LA, et al. Cardiac resynchronization therapy for the treatment of heart failure in patients with intraventricular conduction delay and malignant ventricular tachyarrhythmias. J Am Coll Cardiol 2003; 42: 1454-9.

28. Young JB, Abraham WT, Smith AL, Leon AR, Lieberman R, Wilkoff B, et al. Combined cardiac resynchronization and implantable cardioversion defibrillation in advanced chronic heart failure: the MIRACLE ICD trial. JAMA 2003; 289: 2685-94.

29. Abraham WT, Young JB, Leon AR, Adler S, Bank AJ, Hall SA, et al. Effects of cardiac resynchronization on disease progression in patients with left ventricular systolic dysfunction, an indication for an implantable cardioverter-defibrillator, and mildly symptomatic chronic heart failure. Circulation 2004; 110: 2864-8.

30. Linde C, Leclercq C, Rex S, Garrigue S, Lavergne T, Cazeau S, et al. Long-term benefits of biventricular pacing in congestive heart failure: results from the MUltisite STimulation in cardiomyopathy (MUSTIC) study. J Am Coll Cardiol 2002; 40: 111-8.

31. Cleland JG, Daubert JC, Erdmann E, Freemantle N, Gras D, Kappenberger $L$, et al. Longer-term effects of cardiac resynchronization therapy on mortality in heart failure [the CArdiac REsynchronizationHeart Failure (CARE-HF) trial extension phase]. Eur Heart J 2006; 27: 1928-32.

32. Gervais R, Leclercq C, Shankar A, Jacobs S, Eiskjaer H, Johannessen $A$, et al. Surface electrocardiogram to predict outcome in candidates for cardiac resynchronization therapy: a subanalysis of the CARE-HF trial. Eur J Heart Fail 2009; 11: 699-705.

33. Madaric J, Vanderheyden M, Van Laethem C, Verhamme K, Feys A, Goethals $M$, et al. Early and late effects of cardiac resynchronization therapy on exercise-induced mitral regurgitation: relationship with left ventricular dyssynchrony, remodelling and cardiopulmonary performance. Eur Heart J 2007; 28: 2134-41.

34. Fukuda S, Grimm R, Song JM, Kihara T, Daimon M, Agler DA, et al. Electrical conduction disturbance effects on dynamic changes of functional mitral regurgitation. J Am Coll Cardiol 2005; 46: 2270-6.

35. Vinereanu D, Turner MS, Bleasdale RA, Mumford CE, Cinteza M, Frenneaux MP, et al. Mechanisms of reduction of mitral regurgitation by cardiac resynchronization therapy. J Am Soc Echocardiogr 2007; 20: $54-62$.

36. Kanzaki H, Bazaz R, Schwartzman D, Dohi K, Sade LE, Gorcsan J 3rd, et al. A mechanism for immediate reduction in mitral regurgitation after cardiac resynchronization therapy: insights from mechanical activation strain mapping. J Am Coll Cardiol 2004; 44: 1619-25.

37. Sutton MG, Plappert T, Hilpisch KE, Abraham WT, Hayes DL, Chinchoy E. Sustained reverse left ventricular structural remodeling with cardiac resynchronization at one year is a function of etiology: quantitative Doppler echocardiographic evidence from the Multicenter InSync Randomized Clinical Evaluation (MIRACLE). Circulation 2006; 113: 266-72. 
38. Yu CM, Chau E, Sanderson JE, Fan K, Tang MO, Fung WH, et al. Tissue Doppler echocardiographic evidence of reverse remodeling and improved synchronicity by simultaneously delaying regional contraction after biventricular pacing therapy in heart failure. Circulation 2002; 105: 438-45.

39. Breithardt OA, Stellbrink C, Herbots L, Claus P, Sinha AM, Bijnens B, et al. Cardiac resynchronization therapy can reverse abnormal myocardial strain distribution in patients with heart failure and left bundle branch block. J Am Coll Cardiol 2003; 42: 486-94.

40. Goland S, Rafique AM, Mirocha J, Siegel RJ, Naqvi TZ. Reduction in mitral regurgitation in patients undergoing cardiac resynchronization treatment: assessment of predictors by two-dimensional radial strain echocardiography. Echocardiography 2009; 26: 420-30.

41. Ypenburg C, Lancellotti P, Tops LF, Boersma E, Bleeker GB, Holman $E R$, et al. Mechanism of improvement in mitral regurgitation after cardiac resynchronization therapy. Eur Heart J 2008; 29: 757-65.

42. Dickstein K, Vardas PE, Auricchio A, Daubert JC, Linde C, McMurray J, et al. 2010 Focused Update of ESC Guidelines on device therapy in heart failure: an update of the 2008 ESC Guidelines for the diagnosis and treatment of acute and chronic heart failure and the 2007 ESC guidelines for cardiac and resynchronization therapy. Developed with the special contribution of the Heart Failure Association and the European Heart Rhythm Association. Eur Heart J 2010; 31: 2677-87.

43. Beshai JF, Grimm RA, Nagueh SF, Baker JH, 2nd, Beau SL, Greenberg $\mathrm{SM}$, et al. Cardiac-resynchronization therapy in heart failure with narrow QRS complexes. N Engl J Med 2007; 357: 2461-71.

44. Achilli A, Sassara M, Ficili S, Pontillo D, Achilli P, Alessi C, et al. Longterm effectiveness of cardiac resynchronization therapy in patients with refractory heart failure and 'narrow' ORS. J Am Coll Cardiol 2003; 42: 2117-24.

45. Vahanian A, Baumgartner H, Bax J, Butchart E, Dion R, Filippatos G, et al. ESC guidelines on the management of valvular heart disease: the Task Force on the Management of Valvular Heart Disease of the European Society of Cardiology. Eur Heart J 2007; 28: 230-68.

46. Bonow RO, Carabello BA, Chatterjee K, de Leon AC Jr, Faxon DP, Freed MD, et al. 2006 Writing Committee Members, American College of Cardiology/American Heart Association Task Force. 2008 Focused update incorporated into the ACC/AHA 2006 guidelines for the management of patients with valvular heart disease: a report of the American College of Cardiology/American Heart Association Task Force on Practice Guidelines (Writing Committee to Revise the 1998 Guidelines for the Management of Patients With Valvular Heart Disease): endorsed by the Society of Cardiovascular Anesthesiologists Society for Cardiovascular Angiography and Interventions, and Society of Thoracic Surgeons. Circulation 2008; 118: e523-661.

47. Schroder JN, Williams ML, Hata JA, Muhlbaier LH, Swaminathan M, Mathew JP, et al. Impact of mitral valve regurgitation evaluated by intraoperative transesophageal echocardiography on long-term outcomes after coronary artery bypass grafting. Circulation 2005; 112: I293-8.

48. Kang DH, Kim MJ, Kang SJ, Song JM, Song H, Hong MK, et al. Mitral valve repair versus revascularization alone in the treatment of ischemic mitral regurgitation. Circulation 2006; 114: 1499-503.

49. Penicka M, Linkova H, Lang O, Fojt R, Kocka V, Vanderheyden M, et al. Predictors of improvement of unrepaired moderate ischemic mitral regurgitation in patients undergoing elective isolated coronary artery bypass graft surgery. Circulation 2009; 120: 1474-81.

50. Yu CM, Wing-Hong Fung J, Zhang 0 , Sanderson JE. Understanding nonresponders of cardiac resynchronization therapy-current and future perspectives. J Cardiovasc Electrophysiol 2005; 16: 1117-24.

51. Diaz-Infante E, Mont L, Leal J, Garcia-Bolao I, Fernandez-Lozano I, Hernandez-Madrid A, et al. SCARS Investigators. Predictors of lack of response to resynchronization therapy. Am J Cardiol 2005; 95: 1436-40.

52. Salukhe TV, Francis DP, Clague JR, Sutton R, Poole-Wilson P, Henein MY. Chronic heart failure patients with restrictive LV filling pattern have significantly less benefit from cardiac resynchronization therapy than patients with late LV filling pattern. Int J Cardiol 2005; 100: 5-12.

53. Cabrera-Bueno F, Garcıa-Pinilla JM, Pena-Hernandez J, JimenezNavarro M, Gomez-Doblas JJ, Barrera-Cordero A, et al. Repercussion of functional mitral regurgitation on reverse remodelling in cardiac resynchronization therapy. Europace 2007; 9: 757-61.

54. Wu AH, Aaronson KD, Bolling SF, Pagani FD, Welch K, Koelling TM. Impact of mitral valve annuloplasty on mortality risk in patients with mitral regurgitation and left ventricular systolic dysfunction. J Am Coll Cardiol 2005; 45: 381-7. 